\title{
DİASPORA KAVRAMI BAĞLAMINDA ON İKİ ADA TÜRK TOPLUMU
}

\author{
Firat Yaldiz ${ }^{1}$
}

\section{Özet}

Diaspora kavramı, özellikle 20. yüzyılda meydana gelen uluslararası siyasi gelişmelerle doğru orantılı olarak, günümüzde her zamankinden daha sık kullanılan, popüler bir kavram haline gelmiştir. Diaspora kavramına ilişkin bu geniş kullanım alanı, diaspora (olan veya böyle adlandırılan) toplumlarına ilişkin çalışmaları da etkilemiştir. Ev sahibi devletin ülkesinde yaşayan diaspora toplumlarıyla ilişkisi kadar, anavatanın diasporasıyla ilişkileri de güncel bir konu haline gelmiştir. Bu çalışmada, Lozan Antlaşması'nın kapsamı dışında kalan, dolayısıyla uluslararası hukuktan kaynaklanan azınlık statüsüne ve haklarına sahip olmayan On İki Ada Türk Toplumunun mevcut toplumsal dinamikleri açısından diaspora kavramıyla ilişkisi incelenecektir. Özellikle, AB'nin azınlık politikalarında meydana gelen değişim ve dönüşüm bağlamında, grup hakkı kapsamında değerlendirilen azınlık statüsü yerine, bireysel hak taleplerinin, diaspora kimliğinin oluşumuna ve gelişimine katkısı tartışılacaktır.

Anahtar kelimeler: Diaspora, On İki Ada, Avrupa Birliği (AB), azınlık, bireysel haklar.

\section{Abstract}

The concept of diaspora, especially with the effect of the political developments occurred in the 20th century, has become more popular and more common than ever. This wide range of the concept of diaspora, has also affected the studies on diaspora communities. The relations between the host states and diaspora communities have become a topical issue as the relations between the diaspora communities and the homelands. In this study, the Turkish community in Dodecanisos that had been left outside the scope of the Lausanne Treaty and thus stemming from the minority rights and minority status will be searched in relation with the concept of diaspora in terms of the social dynamics. In particular, in the context of the change and transformation of EU's minority policies, contribution of individual rights claims instead of the minority status and its effect to the formation and development of diaspora identity will be discussed.

Key Words: Diaspora, dodecanisos, European Union, minority, individual rights.

\footnotetext{
${ }^{\text {I}}$ Dr. Başbakanlık YTB, firatyaldiz@gmail.com
} 


\section{Giriş}

Diaspora kavramı, uluslararası göç hareketlerinin sayısal olarak artması ve sosyal etkisinin güçlenmesiyle, güncel bir tartışma alanı haline gelmiştir. Literatürde kavramın tarihsel köklerine ilişkin etimolojik araştırmalar, diasporaların özellikleri, sınıflandırılması, anavatan ve ev sahibi devletlerle ilişkileri gibi birçok alanı da kapsayacak şekilde ve disiplinler arası bir bakış açısıyla tartışılmaktadır. Bu bağlamda, kimlerin diaspora olarak tanımlanabileceği ve uluslararası göçün bu kavramsal tartışmalara etkisi son dönemlerde daha yoğun bir şekilde incelenmektedir.

Kuramsal bir çerçeveye sığdırılamayacak kadar geniş bir kullanım alanına sahip olan kavram, daha çok Batı dünyasında araştırılmakta ve tartışmalar da Batılı bir retorik üzerinden yürütülmektedir. Bir eleştiri değil bir tespit olarak vurgulanan bu durumun, genelde doğudan batıya doğru göçün bir sonucu olduğu düşünülebilir. Binlerce yıldır ve genelde batıya doğru devam etmekte olan göç, "Doğu”ya akraba devlet (anavatan), "Batı”ya ise ev sahibi devlet (vatan) rolünü vermiş, Batıda yaşayan Doğulu toplumların, Batılı bir gözle incelenmesi de, diaspora araştırmalarının genel karakteristiği olmuştur. Nitekim literatürde de, İsrail'deki Amerikan diasporasından değil de ABD'deki Yahudi diasporasından bahsedilmesi veya Ermenistan'da yaşayan Fransızların değil Fransa'daki Ermeni diasporasının etkinliğinin vurgulanması, tarihsel ve güncel (doğudan batıya) göç sürecinin doğal bir sonucudur. Bu bağlamda, diaspora konusuyla ilgili temel kitapların çok büyük bir bölümünün de, Batılı yazarlar tarafından, Batılı üniversitelerde yazılmış ve basılmış olduğunu belirtmekte yarar vardır. (Yaldız, 2013, s. 291)

Türk diasporasını oluşturma ve/veya diaspora ile bağlarını güçlendirme çabası içerinde olan Türkiye Cumhuriyeti de Dışişleri Bakanlığı, Milli Eğitim Bakanlığı, Diyanet İşleri Başkanlığı, Türk İşbirliği ve Koordinasyon Ajansı gibi köklü kurumlarını yurtdışındaki varlığını da kapsayacak şekilde yeniden yapılandırırken, vatandaş, soydaş, akraba kavramları çerçevesinde yürütülen çalışmaları Başbakanlık Yurtdışı Türkler ve Akraba Topluluklar Başkanlı̆̆ı ve Yunus Emre Vakfi gibi yeni kurumsal yapılarla güçlendirmektedir. Bu çalışmada da Türkiye'nin, üçyüzdoksan yıl süren (1522-1912) Osmanlı hâkimiyeti sona erdikten sonra bile ilişkilerini kesintisiz bir şekilde sürdürdüğü On İki Ada'da yaşayan Türk toplumu, bu bakış açısıyla incelenecektir. Lozan Antlaşması'nın dışında kaldığı için, uluslararası hukuktan kaynaklanan bazı haklardan da 
mahrum olan ve hukuki anlamıyla azınlık statüsüne sahip olmayan "Ege'nin unutulmuş Türkleri”"2, diaspora kavramına ilişkin tartışmalara katkı sağlayabilecek durumdadır.

Ancak tam da bu noktada vurgulanması gereken önemli bir konu da şudur ki diaspora kavramına ilişsin akademik tartışmalar, Türkiye akademisinde yeterince ilgi görmemiş ve Türk Diasporası kavramı a priori olarak kullanılır olmuştur. Türk diasporasının öznesi olarak kullanılan (i) vatandaş, (ii) soydaş, (iii) akraba kavramları yasal ve/veya akademik olarak tanımlanmamış, Türk Diasporasının kimlerden oluştuğu, kimlerin Türk Diasporasının parçası olduğu sorgulanmamıştır. Hatta bir “Türk diasporası var mıdır?” sorusu bile, cevaplanmak bir yana, sorulmamıştır. Bu çalışmada da -başka bir çalışmanın konusu olması gereken- bu sorulara cevap aranmayacak, On İki Ada Türklerinin biricik durumundan hareketle Türk diasporasına ilişsin çalışmalara ihtiyacın önemi vurgulanacaktır. Nitekim coğrafi, hukuki, tarihsel ve siyasal anlamda farklılıklar gösteren Türkiye dışındaki Türklerin, Batılı çalışmalar üzerinden incelenmesi ve Batılı kavramlarla anlatılması son derece önemli bir eksikliktir. Bu eksiklik, On İki Ada Türklerine ilişkin bir case study yapılmasına olanak vermemektedir. Bu durum, diaspora çalışmalarına ilişkin edilgen değil etkin bir tutum benimsenmesi ihtiyacını ortaya koymaktadır. Bu çalışmada da özellikle On İki Ada Türkleri gibi spesifik ve görece küçük bir toplum üzerinden, Türk diaspora kavramına ilişkin çalışmaların önemi vurgulanmaktadır.

On İki Ada Türk Toplumunun diaspora kavramıyla ilişkisini incelemeden önce, genel çerçeveye katkı sağlayacak tarihsel ve toplumsal süreçlerden bahsetmek uygun olacaktır. On İki Ada kavramı, Yunanca oniki anlamına gelen dodeca ve adalar anlamına gelen nesos kelimelerinden oluşan dodecanesos'tan gelmekte ve “[a]dı bir sayıya işaret eder gibi algılansa da aslında On İki Ada, Güney Ege'de ada görünümünde 14’ü büyük 20 kadarı küçük olmak üzere irili ufaklı çok sayıda kara parçasını” ifade etmektedir (Dilek, s.30-31). Rodos adası ve İstanköy adası, On İki Ada içerisindeki en önemli iki adadır; ancak Rodos adası yüzölçümü açısından en büyük, Türk toplum nüfusu açısından en kalabalık ve kültürel miras açısından ${ }^{\mathrm{i}}$ en zengin olan adadır (Çelikkol, 1992, s. 1-28).

On İki Ada, 1522'de Osmanlı Devleti tarafından alınmış, 1912 yılına kadar da Osmanlı yönetiminde kalmıştır. 1912 yılında İtalya tarafindan işgal edilen On İki Ada, İkinci Dünya Savaşı sürerken Alman işgaline uğramış; savaşın ardından 1947 yılında Yunanistan'a bırakılmıştır. (Bastıyalı, 1999) On İki Adanın Osmanlı yönetimi altına girmesinin ardından Anadolu'dan getirilen Türk nüfus, günümüze kadar varlığını devam ettirmiş olup, günümüzde yaklaşık 5000 civarında Türk kökenli insanın yaşadığı belirtilmektedir (Meinardus, 2002, s. 82-93).

\footnotetext{
${ }^{2}$ Bu doğru tanımlama, Bahadır Selim Dilek'in kitabının adıdır. Bkz.: Bahadır Selim Dilek, Ege'nin Unutulan Türkleri, Cumhuriyet Kitapları, İstanbul, 2008.
} 
46 Firat Yaldız

On İki Ada Türk toplumunun, diasporik açıdan tartışılmasından önce belirtilmesi gereken önemli bir konu, bu insanların günümüzde -birçok yasal ve sosyal soruna rağmen- Türkçe bilen/konuşan, Türk olduklarının bilincinde olan, anavatanla ilişkileri devam eden ve dini kimliklerini koruyan bir toplum olduklarıdır.

Çalışmada, On İki Ada Türk toplumuna ilişkin, yukarıda belirtilen özet bilgiyle yetinilecek, tarihsel, hukuksal ve toplumsal sürece ilişkin ayrıntılardan -başka bir çalışma konusu olabileceği için- daha fazla bahsedilmeyecektir. Bu noktada vurgulanması gereken önemli bir eleştiri de On İki Ada Türk toplumuna ilişkin araştırmaların ve akademik altyapının son derece zayıf olduğudur. Bu durumun, nüfusu yaklaşık 100.000'e ulaşan Batı Trakya Türklerinin ${ }^{3}$ "Yunanistan'daki Türkler" konusuna ilişsin çalışmaların temel öznesi olarak kabul edilmesinden kaynaklandığı düşünülmektedir.

Çalışmada, diaspora kavramına ilişkin güncel gelişme ve tartışmalara yer verilerek, kavramsal çerçeve çizilmeye çalışılacaktır. Bu amaçla, kavramın tarihsel kökleri, günümüzdeki farklı anlamları ve çağrışımları incelenecek, diaspora çalışmalarında önemli eserler veren akademisyenlerin bakış açıları aktarılacak ve kavramın güncel bağlamı araştırılacaktır. Bu kavramsal tartışmaların ardından, On İki Adada yaşayan Türklerin durumu, diaspora kavramına ilişkin tartışmalar ekseninde incelenecek ve "On İki Ada Türk Toplumu diaspora mıdır?” sorusuna cevap aranacaktır.

\footnotetext{
${ }^{3}$ Batı Trakya Türkleri ile ilgili ayrıntılı bir çalışma için bkz.: Turgay Cin, Yunanistan’daki Türk Azınlığın Hukuki Özerkliği, Orion Kitabevi, Ankara, 2009.
} 


\section{Diaspora Kavramı}

Antik Çağ’ dan beri var olan diaspora ${ }^{4}$ olgusu, günümüzde de yoğun bir tartışmanın öznesi haline gelmiştir. 1990 yılında dünya genelinde yaklaşık 154 milyon göçmen varken, 2000 yılında bu sayı 175 milyonu, 2013 yılında ise 232 milyonu bulmuştur. ${ }^{5}$ Uluslararası sistemde meydana gelen böylesine hızlı ve büyük bir hareketlilik, diaspora kavramının kullanımını da fazlasıyla arttırmıştır. "Vaktiyle Yahudilerin, Yunanlıların ve Ermenilerin dağılmasını tarif eden diaspora kelimesi, artık 'göçmen', 'vatansız', 'mülteci', 'misafir işçi', 'sürgün topluluğu', 'yurtdışı topluluğu', 'etnik topluluk' gibi terimleri kapsayan daha geniş bir anlambilimsel alana” karşıllk gelmektedir. (Tölölyan, 1991, s. 4) Yine son dönemlerde, diasporanın anlamı da belirsizleşmektedir. “ABD’deki Yahudi diasporası" bir topluluğu, "diasporada yaşayan Yahudiler” bir ülke/bölgeyi, "diasporada doğan Yahudiler, diasporalı Yahudiler" coğrafi bir yeri/mekânı, "diasporizm” bir ideolojiyi, "diasporik" sosyal bir akımı anlatmaya çalışan yan kullanımlardır. Bazı ülkelerde ise expatriate (ülke dışında yaşayan), oversea (denizaşırı ülkelerde yaşayanlar) ve ressortissant (uyruk) gibi diaspora kavramına yakın anlamlı kelimeler kullanılmaktadır. Ayrıca diaspora kavramı, kimlik, etni, ulus, göç, getto, ve azınlık gibi kavramlarla da yakın ilişki içerisindedir (Yaldız, 2014).

Kuramsal bir çerçeveye sığdırılamayacak kadar geniş bir kullanım alanına sahip olan kavram, daha çok Batı dünyasında araştırılmakta ve tartışmalar da Batılı bir retorik üzerinden yürütülmektedir. Bir eleştiri değil bir tespit olarak vurgulanan bu durumun, genelde doğudan batıya doğru göçün bir sonucu olduğu düşünülebilir. Binlerce yıldır ve genelde batıya doğru devam etmekte olan göç, “Doğu”ya akraba devlet (anavatan), "Batı”ya ise ev sahibi devlet (vatan) ${ }^{6}$ rolünü vermiş, Batıda yaşayan Doğulu toplumların, Batılı bir gözle incelenmesi de diaspora araştırmalarının genel karakteristiği olmuştur. Nitekim literatürde de İsrail'deki Amerikan diasporasından değil de ABD'deki Yahudi diasporasından bahsedilmesi veya Ermenistan'da yaşayan Fransızların değil Fransa'daki Ermeni diasporasının etkinliğinin vurgulanması, tarihsel ve güncel (doğudan batıya) göç sürecinin doğal bir sonucudur. Bu bağlamda, diaspora konusuyla ilgili temel kitapların çok büyük bir bölümünün de Batılı yazarlar tarafından, Batılı üniversitelerde yazılmış ve basılmış olduğunu belirtmekte yarar vardır. Diaspora kavramının, günümüzde Batı'da yaşayan Doğulu toplumlar için kullanıldığı; Doğu'da yaşayan Batılı toplumlar içinse pek tercih edilmediği görülmektedir.

\footnotetext{
${ }^{4}$ Diaspora kelimesi, en basit tanımıyla "sağa sola dağılmış/saçılmış tohumlar" anlamına gelmektedir.

${ }_{6}^{5} \mathrm{http}: / /$ esa.un.org/unmigration/wallchart2013.htm

${ }^{6}$ Ev sahibi devleti, diasporanın yaşadığı ülke devleti; akraba devleti ise, diasporanın kendini etnik, vs. bakımından ait hissettiği devlet olarak tanımlamak mümkündür.
} 
Etnik gruplar, göçmenler ve yabancılarla ilgili akademik tartışmaların birçoğunda ve azınlık-çoğunluk ilişkisi ile ilgili değerlendirmelerde, diaspora kavramına çok az yer verildiği görülmektedir (Safran, 1999, s. 364). Hâlbuki diaspora kelimesi, bu tartışmalar bağlamında önemli bir yere sahiptir. "Tarihin ve talihin öznesi olan insanlık macerasinı anlatan maceraperest bir kelime" (Marienstras, 1999, s. 363) şeklinde betimlenen diaspora kavramının günümüzdeki anlamını kavrayabilmek için, tarihte geriye doğru gitmek gerekir.

Aslında kadim bir kelime olan diaspora, küreselleşmenin etkisiyle -coğrafya, kimlik ve aidiyet gibi kavramlarla ilişsisini alt üst eden- yeni bir anlama sahip olmaya başlamıştır. (Braziel \& Mannur, 2007, s. 1) Etimolojik olarak, Yunanca dia ve sperien kelimelerinin bir araya gelmesiyle oluşan diaspeiro fiilinin kullanımına, M.Ö. 5 yüzyılda Sofokles, Herodotos ve Tukidides’te rastlanmaktadır (Dufoix, 2011, s. 17). Yunanca diaspeiro/diasperien kelimesinden türeyen diaspora kavramı ise, Septuagint'de anavatanları dışında sürgünde yaşayan Yahudileri tanımlamak için ve İskenderiye'de yaşayan Helenik Yahudi topluluklarını kastederek kullanılmıştır. (Braziel \& Mannur, 2007, s. 1) Genel olarak Filistin dışında yaşayan Yahudiler için kullanılır hale gelen diaspora kelimesinin, Yunanlılar tarafindan Küçük Asya ve Akdeniz'in Arkaik dönemde (M.Ö. 800-600) kolonizasyonunu ifade etmek için kullanıldığı da belirtilmektedir. (Cohen, 1999, s. 266)

Daha çok Yahudiler için kullanılan diaspora kavramı, tarihsel süreç içerisinde anayurdundan ayrılan diğer bazı topluluklar için de kullanılır olmuştur. Bu toplulukların başında da Afrikalılar ve Ermeniler gelmektedir.

"Siyah diaspora", ilk olarak Abiola Irele tarafindan Ekim 1965'te yayınlanan Negritude or Black Cultural Nationalism başlıklı makalede (1965) kullanılmıştır. "Afrika diasporası" ise, George Shepperson tarafından The African Abroad or the African Diaspora başlıklı tebliğde (1966) kullanılmıştır. Dufoix (2011, s. 22), bu terimlerin 1950 'lerden itibaren entelektüel çevrelerde dolaşımda olan terimler olduğunu belirtmektedir. Paul Gilroy’un 1993 yılında yayınladığı ve Afrika diasporasını, Afrika tarihi ve kültürü bağlamında ele alan The Black Atlantic: Modernity and Double Consciousness isimli kitabı (1993) diaspora çalışmalarına yapılan en önemli ve güncel katkılardan biridir.

Binlerce yıldır süren dağılmışlıklarına rağmen Ermeniler, 19. yüzyıla kadar "diaspora" kavramıyla tanımlanmazlar. Bu dönemde Almanya'da, İngiltere'de ve ABD'de sıkça kullanılmaya başlanan diaspora kelimesi, dinleri etrafinda birleşmiş Ermeniler gibi halklara da gönderme yapmaktadır. (Dufoix, 2011, s. 26) 1931'de Simon Dubnov, Encyclopedia of the Social Science'1n diaspora maddesinde Ermenileri örnek olarak gösterir:

"Diaspora, kendi devletinden ya da yurdundan ayrılmış ve başka uluslar arasında dağılmış, ancak [,] kendi ulusal kültürünü koruyan bir ulus ya da ulusun bir parçası için kullanılan, Yunanca bir terimdir. ..... 
Ege Strategic Research Journal

Diasporanın tipik bir örneği, çoğu yüzyıllardır kendi ulusal küçük yurtlarının dışında gönüllü olarak yaşayan Ermenilerdir...." (Dufoix, 2011, s. 27).

Diaspora kavramını Yahudiler için kullanılan özel bir isim olmaktan çıkararak, benzeri tarihsel tecrübeleri yaşamış diğer topluluklar için de kullanılabilmesinin önünü açan bu tanım, kavramın gelişimine de katkı sağlamıştır. Nitekim “Dubnov’un metni, 'diaspora' teriminin yayılmasında önemli bir rol oynar; genel olarak sekülerleşmesini, özel olarak da Yahudi halkının tarihsel deneyiminden yavaş yavaş kopmasını sağlar” (Dufoix, 2011, s. 27). Bazı akademisyenler, Dubnov’un yaklaşımını, diaspora kelimesini sınırlı (sadece Yahudiler için) kullanma çağrısı olarak okurken, bazıları da bu yaklaşımı kavramsal bir açı1ım olarak görürler. Robert Park, 1939'da Dubnov'un yaklaşımını daha da genişleterek, diaspora kelimesini Asyalılar için de kullanır (Park 1939, aktaran Dufoix, 2011, s. 28).

Diaspora kavramındaki bu genişleme, 1960'larda etkisini iyice gösterir, gazete ve sözlükler de bu geniş yaklaşımdan etkilenir. 1961'de Webster, kavramı “ortak ulusal kökene ya da inanç ortaklığına sahip insanların dağılması ve bir ülkenin başka ülkelere dağılmış halkı" olarak tanımlar (Dufoix, 2011, s. 28). Le Monde 1968'de “Çek diasporası” terimini kullanır (Dufoix, 2011, s. 28). Pierre Gilbert, Dictionnaire des mots contemporains'de tanımın "Yahudilerin yanı sıra başka halkları da kapsayacak şekilde" genişletilmesini benimser. (Gilbert, 1980, aktaran Dufoix, 2011, s. 28) Encyclopedia of the Social Science'dan 1968 'te çıkarılan diaspora maddesi ise, 2001 yllında Robin Cohen'in metniyle yeniden yer alır (Cohen, 2001, s. 3642-3645).

Sonuç olarak, diaspora kavramına ilişsin gelişmeler iki önemli noktadan devam etmiştir. İlk olarak, kavramın ortaya çıkışı ve ilk anlamı, doğrudan ve sadece Yahudilerle ilişkilendirilmiş; neredeyse bir özel isim gibi kullanılmıştır. Ancak tarihsel süreçte göç, sürgün gibi benzeri deneyimleri yaşayan diğer halklar da özellikle 19. yüzyıldan sonra diaspora olarak değerlendirilmeye ve dolayısıyla kavramın tanımı genişlemeye başlamıştır. Afrikalılar ve Ermeniler bu kavramsal açılımın başat aktörleri olarak görülse de Yunanlılar, Hintliler, Çinliler, Kürtler, Filistinliler ve daha birçok topluluk, diaspora tanımının bağlamına dâhil olabilmektedir. İkinci olarak, Avrupa dillerinde neredeyse 20. yüzyılın ortalarına kadar yalnızca ilahiyat veya din incelemeleri alanlarının konusu olan (Dufoix, 2011, s. 26) diaspora kavramı, günümüzde seküler bir anlam kazanmış ve daha çok etnik bir çerçeveye ulaşmıştır. 


\section{Diasporaların Özellikleri ve On İki Ada Türk Toplumu}

Diaspora çalışmaları konusunda, en yetkin isimlerden biri olduğu kabul edilen ve en çok atıf yapılan yazarlar arasında yer alan William Safran, kavramın içeriğinden çok niteliği üzerinde durmaktadır. Safran, "Diasporas in Modern Societies: Myths of Homeland and Return" başlıklı makalesinde, diasporanın "ne olduğu” değil "nasıl olduğu”nu tartışarak, bir diaspora grubunun altı temel özelliğini şöyle sıralamaktadır (1999, s. 364-365):

1- Kendileri veya ataları, belirli bir merkezden, iki veya daha fazla (çevre veya yabancı) bölgeye dağılmışlardır.

2- Anavatana ilişkin (fiziki konumu, tarihi ve başarılarını da kapsayan) ortak bir hafıza, vizyon veya mitosu korurlar.

3- Misafir oldukları toplum tarafindan, tam olarak kabul görmediklerine ve muhtemelen de asla kabul görmeyeceklerine inanırlar ve bu yüzden kendilerini kısmen yabancı ve izole edilmiş hissederler.

4- Tarihsel anavatanlarını, kendilerinin gerçek, ideal evi olarak kabul ederler; şartlar uygun olduğunda kendileri veya sonraki nesiller, anavatana geri dönecektir/dönmelidir.

5- Hep birlikte, anavatanın korunması veya yeniden yapılandırılması ve anavatanın güvenliği ve refahı için çalışmaları gerektiğine inanırlar.

6- $\quad$ Anavatanla bağlarını korumaya devam ederler ve etnik bilinçleri ve dayanışmaları, önemli ölçüde bu ilişki üzerinden tanımlanır.

Safran (1999, s. 364-365), bu özelliklerin hemen ardından, bu tanım bağlamında "hiçbiri Yahudi diasporasının ‘ideal tip’ini tam olarak karşılamasa da günümüzde Ermeni, Mağribi (K.Afrika), Türk, Filistin, Küba, Yunan ve belki Çin diasporalarından” bahsedilebileceğini belirtmektedir.

Safran'ın belirttiği bu özellikler, 20. yy. başlarındaki Yahudi diasporasının durumuyla örtüşmektedir. Ancak günümüzde kendini diaspora olarak adlandıran birçok grubun (Çin, Meksika, Afrika diasporaları) ve hatta Yahudi diasporasının dahi, bu özelliklerin bir kısmını (anavatana geri dönme düşüncesi, ev sahibi toplum tarafından kabul edilmedikleri inancı gibi) taşımadığı görülmektedir. Sideri (2008, s. 32-47), Safran’ı travma, sürgün ve nostalji üzerinden tanımlama yapmakla eleştirmekte ve diaspora kavramını tanımlamaya çalışmanın, bizi, diasporanın bir kuramsal çerçeve olarak ortaya çıktığı tarihsel bağlamı sınamaya zorladığını; bunun ise tarihsel deneyimlerin, eğilimlerin ve gündemlerin çokluğu/farklılığı nedeniyle imkânsız bir uğraş olduğunu belirtmektedir. 
Diaspora çalışmalarının en önemli eserlerinden biri olan 1997 tarihli "Global Diasporas: an introduction" kitabının yazarı Robin Cohen de (1997, s. 4), Safran'ın diaspora algısının ve özellikle anavatan (homeland) vurgusunun, Yahudi diasporasının gelenek ve deneyimlerinden fazlasıyla etkilendiğini belirtmektedir. Cohen, hem Yahudi diasporasının genel özelliklerini ve hem de gittikçe daha geniş bir anlamda kullanılan diaspora teriminin gelişimini kapsayacak bir kavramsal çerçeve çizilmesi gerektiğini vurgulamakta (1997, s. 5) ve dokuz özellik sıralamaktadır (1997, s. 180-187):

1- Anayurttan genellikle travmatik bir şekilde ayrılma,

2- (ya da) Anayurttan iş aramak, ticaret veya kolonyal amaçlar gibi nedenlerle ayrılma,

3- Kolektif bir hafıza ve anayurda ilişsin mitos,

4- Varsayılan anayurdun idealize edilmesi,

5- Geri dönüş hareketleri,

6- Uzun zamandan beri devam ettirilen güçlü bir etnik grup bilinci,

7- Ev sahibi toplumlarla sorunlu bir ilişki,

8- Diğer ülkelerdeki soydaşlarla birlikte dayanışma duygusu,

9- Hoşgörülü ev sahibi devletlerde, daha iyi bir yaşam kurma ihtimali.

Cohen'in belirttiği bu özellikler içerisinde, özellikle ikisi, diaspora toplumlarını günümüz koşullarında tahlil edebilmek için, son derece önemli kriterlerdir. Diaspora kavramını, "anayurttan travmatik bir şekilde ayrılma" şartına bağlayan yaklaşım yerine, diaspora toplumlarının "anayurttan iş aramak, ticaret veya kolonyal amaçlar gibi nedenlerle ayrılma" neticesinde de oluşabileceğini kabul etmek, 21. Yüzyılın toplumsal, siyasal, küresel ve ekonomik gerçekleriyle örtüşmektedir. Cohen'in ikinci değerli katkısı da “diğer ülkelerdeki soydaşlarla birlikte dayanışma duygusu"nu vurgulamış olmasıdır. Ulaşım, haberleşme gibi alanlarda meydana gelen gelişmelerin de etkisiyle, diasporaların sadece anavatanla değil diğer ülkelerdeki soydaşlarıyla da işbirliği ve dayanışma içerisinde olması, diasporaların küresel aktörler olabilmeleri için de önemlidir.

Cohen yukarıda bahsedilen özelliklere ek olarak, Clifford'a atıfla (1994, s. 302-338) diasporaların asla "sadece milliyetçi" olamayacaklarını da belirtmektedir (1997, s. 135). Diasporalar, kendi ulusal kimlikleri ile yaşadıkları ülkenin ulusal kimliği arasındadır. Her ne kadar bazı diasporaların bünyelerinde kendi ulus-devletlerini kurmak isteyen milliyetçi gruplar yer alsa da ulusal bilince ilişkin özlem, ordusu, polisi, bayrağı olan BM üyesi bir devlet kurma ideali boyutunda değildir. Diasporalar, ulus-devlet ile "seyahat eden kültürler” (travelling cultures) 


\section{Firat Yaldız}

arasında bir yerdedir; fiziki bağlamda bir ulus-devlette yaşarlar ancak duygusal olarak ulus-devlete ilişkin zaman ve mekânın ötesindedirler (Cohen, 1997, s. 135-136).

Rogers Brubaker, 2005 yılında yazdı̆̆ı "The 'diaspora' diaspora" başlıklı makalesinde ise 3 kriter belirlemektedir (2005, s. 1-19): (i) Dağıllma, (ii) Anayurda yönelim, (iii) Psikolojik sınırların korunması. Brubaker'ın yaklaşımının, diğer eserlere kıyasla daha yüzeysel ve bazı noktalarının açıklamaya muhtaç olduğu görülmektedir.

Sheffer (2003, s. 9-10), etno-ulusal diasporaları şöyle tanımlamaktadır: (i) Zorunlu veya gönüllü göç sonucu oluşmuştur. (ii) Üyeleri, aynı etno-ulusal kökenden geldiklerini kabul eder. (iii) Anavatan dışındaki bir veya daha fazla ülkede ve azınlık olarak yaşamaktadırlar. (iv) Üyeleri, hem anavatanla hem de diğer ülkelerdeki soydaşlarıyla bağlarını sürdürürler. (v) Üyeleri hem diasporanın diğer üyeleriyle hem de bütün bir ulusla dayanışma içindedir; kültürel, sosyal, ekonomik ve politik açıdan aktiftirler. (vi) Diğer birçok faaliyetlerinin yanı sıra, diaspora üyeleri diasporalar, ev sahibi devletler, anavatan ve uluslararası aktörler arasındaki kompleks ilişkiyi etkileyecek devlet-ötesi (trans-state) iletişim ağları kurarlar.

Sheffer da -Cohen gibi- zorunlu göç kriterini aşan bir bakış açısıyla gönüllü göçün de diasporaların oluşumuna neden olabileceğini belirtmektedir. Ayrıca, yine Cohen'in belirttiği “diğer ülkelerdeki soydaşlarla birlikte dayanışma duygusu"nu Sheffer'ın daha da ileri taşıyarak diaspora üyelerinin, hem anavatanla hem de diğer ülkelerdeki soydaşlarıyla bağlarını sürdürdüklerini, dayanışma içinde olduklarını; kültürel, sosyal, ekonomik ve politik açıdan aktif olduklarını ve diasporalar, ev sahibi devletler, anavatan ve uluslararası aktörler arasındaki kompleks ilişkiyi etkileyecek devlet-ötesi iletişim ağları kurduklarını belirtmesi, diaspora olgusuna son dönemlerde yapılmış en değerli katkılardan biridir.

Farklı yazarların görüşlerine yer verilen bu bölümde, son olarak bir topluluğun diaspora olarak adlandırılabilmesi için "zaman" unsurunun önemine vurgu yapmak yerinde olacaktır. Marienstrass (1999, s. 363), “[D]iaspora kelimesi bugün, ev sahibi toplumda görünür büyüklükte bir sayıya sahip tüm göçmen toplumları tanımlamak için kullanılmaktadır. Fakat [bu toplumların] gerçekten diaspora olup olmadığını bilmek için, zaman geçmesi gerekir.” demektedir. Cohen de -Marienstrass'a atıfla- bir göçmen topluluğunun başka bir ülkeye ulaşması ile doğrudan bir diaspora kurulmuş olamayacağını, ABD'de ise bu hatanın yaygın bir şekilde yapıldığını belirtmektedir. Diasporik bilincin oluşması veya korunması için, geçmişle güçlü bir bağ ve/veya bugün ve yarın asimilasyona karşı direnç olmalıdır (Cohen, 1997, s. 186). Toplumun bir statüden (göçmen) diğer statüye (diaspora) geçişi bağlamında, göçmen toplumları diaspora toplumlarına dönüştüren noktayı araştırmak, çalışmamız açısından önem arz etmektedir. Somuta indirgenmiş tarih ve tanımları da (ev sahibi devlete varış 
tarihi, vatandaşlık başvuru tarihi, vatandaşlığ 1 aldığ 1 tarih, yerleşikliğin bir göstergesi olarak iş bulduğu ve/veya ev satın aldığı tarih gibi), sosyal ve psikolojik araştırmaları da bir yana koyan Sheffer, bu sorunsala değerli bir soruyla karş1lık vermektedir (2003, s. 17). Diaspora toplumunun üyeleri, neden sadece kimliklerini korumakla yetinmeyerek, bu kimlikle tanımlanmak, bir diaspora çatısı altında örgütlenmek, harekete geçmek ve hem anayurtla hem de diğer ülkelerdeki soydaşlarıyla bağlarını korumak isterler? Cevabı, coğrafya, anayurt, ev sahibi devlet, etnik kimlik gibi olgulara göre farkl1lık gösterecek bu sorunun, belli bir diaspora toplumunu ve genel olarak diaspora kavramını anlayabilmek için son derece anlamlı olduğu düşünülmektedir.

Diaspora oluşumunu, belli bir süre geçtikten sonra da ortak bilincin sürüyor olmasına bağlayan bu görüşlere ek olarak, diaspora topluluklarındaki genç ve yaşlı üyeler arasında doğması muhtemel iletişim sorunlarını da göz önüne almak gerekir. Anayurtta doğan ve ev sahibi devlete göç eden birinci kuşak ile ev sahibi devlette doğan ikinci kuşağın bakış açıları arasında önemli farklılıklar bulunabilir. Bu durumun, kuşaklar arası iletişimin kopmaması ve diaspora bilincinin devam etmesi açısından önemi bağlamında, Radhakrishnan (2007, s. 123) iki kuşak arasında "empati” yapılabilmesinin önemini vurgulamaktadır. Lowe (2007, s. 132-155) ise, birinci ve ikinci kuşak arasındaki uyumsuzluk bağlamında, kültürü kuşaktan kuşağa ve dikey olarak aktarılan değişmez bir olgu olarak görmek yerine, bir toplumdan diğerine -1rk, cinsiyet, ve milliyet çizgilerinin de ötesine geçerekyatay olarak aktarılabilen bir olgu olarak yorumlamayı tavsiye etmektedir.

Yukarıda bahsedilen bu çalışmaların temelinde yatan sorunsal, günümüzde neredeyse anavatanının dışında yaşayan herkes için (göçmen, mülteci, işçi, işadamı, öğrenci) diaspora kavramının kullanılması ve bu fazlasıyla geniş kullanımın diaspora kavramının anlamını bulandırmasıdır. Bu bağlamda ortaya atılan en temel soru “anayurt dışında yaşayan herkes (bir etnik grup), doğal olarak diaspora mıdır?” sorusudur (Reis, 2004, s. 42). Diasporaların özelliklerini belirlemek amacıyla yukarıda incelenen çalışmalardan da görüldüğü üzere, literatürde bu soruya verilen cevap "Hayır"dır; ama kimlere, ne zaman ve hangi koşullarda diaspora denilebileceği de net bir şekilde ortaya konulamamıştır. Diasporaların özelliklerinin neler olduğu ve hangi grupların diaspora olarak adlandırılabileceği gibi konularda, henüz net ve ortak bir yaklaşım bulunmamaktadır. Ancak günümüzdeki tartışma ve gelişmelerin, 'diasporanın oluşumuna, sadece zorunlu göçün değil iş, eğitim, ticaret, evlilik gibi nedenlerle gerçekleşen gönüllü göçün de kaynaklık edebileceği' ve ‘diasporaların diğer ülkelerdeki soydaşlarıyla da iletişim ve işbirliği içerisinde olması gerektiği’ hususları, kavramın güncel yorumuna en önemli katkılardır.

Oniki Ada Türk Toplumunun durumu incelendiğinde, öncelikle “anavatandan göç” konusu önemli bir sorunsal olarak karşımıza çıkmaktadır. Nitekim kavramsal ve kuramsal tartışmalar, diasporanın yaşadığı yerin anavatan olma ihtimali üzerinde durmamaktadır. 1522 yılından itibaren, Anadolu'dan göç ederek On İki Adaı anavatan 


\section{Firat Yaldız}

olarak kabul etmiş Türk toplumu için ev sahibi devlet ve akraba devlet ayrımı, literatürdeki kesin çizgilerle ayrılabilir netlikte değildir. Nitekim bu kavramlar, On İki Ada özelinde iç içe geçmiş görünmektedir.

İkinci olarak, On İki Ada Türk toplumunun göçleri, yaklaşık 500 y1l öncesine götürülebilse dahi, 16. yüzyılda başlayan bu göçün, aynı devlet içerisinde meydana gelen bir göç olarak değerlendirilmesi gereklidir. Bu durum, diaspora araştırmalarına yeni bir boyut katması ve yeni bir tartışma açması gerektiğine inanılmaktadır.

Üçüncü olarak ise, kolektif hafiza, etnik bilinç ve diğer ülkelerdeki soydaşlarla ilişkiler gibi diaspora özelliklerine ilişkin konularda da açık bir kabulün (veya reddin) söz konusu olmadığı görülmektedir. Diasporaların özellikleri arasında sayılabilecek bu başlıklar, Oniki Ada Türk Toplumu için kısmen geçerlidir. Dil, din, kimlik üzerinden kurgulanan toplumsal yapı, günümüzde zayıflamakla beraber varlığını halen korumaktadir. 


\section{Diasporaların Sınıflandırılması ve On İki Ada Türk Toplumu}

Diasporanın tanımı ve özelliklerine ilişkin yukarıda açıklanan tartışma, diasporaların sınıflandırılmasına da yansımış, sınıflandırma sorunu bu tartışmayı kavramsal anlamda yeni boyutlara taşımıştır.

Armstrong, 1976 yılında yazdığı “Mobilized and Proletarian Diasporas” başlıklı makalesinde, (1976, s. 393-408) seferber (mobilized) diasporalar ve emekçi (proletarian) diasporalar olmak üzere ikili bir sınıflandırma yapar. Emekçi diasporalar, modern yönetimlerin dezavantajlı ürünleridir. Seferber diasporalar ise çok etnili yönetim altında -statülerine ilişkin özel bir avantajları olmamakla beraber- diğer gruplarla kıyaslandığında fiziksel ve kültürel anlamda çok daha avantajlı olan etnik gruplardır (Armstrong, 1976, s. 393).

Sheffer ise, 1986 yılında yazdığı “A New Field of Study: Modern Diasporas in International Politics” başlıklı makalede, diasporaları başka bir bakış açısıyla sınıflandırmayı teklif eder (1986, s. 1-15): Tarihsel diasporalar ve Modern diasporalar. Yahudi, Ermeni ve Yunan diasporaları gibi tarihsel diasporalara ek olarak, günümüzde yeni bir fenomen olarak ortaya çıkan modern diasporalar, anavatanları dışında başka bir ev sahibi devlette yaşayan, fakat anavatanlarıyla duygusal ve fiziksel bağlarını güçlü bir şekilde sürdüren göçmen orijinli etnik azınlık gruplarıdır. Modern diasporalar, Avrupa’ya, Kuzey Amerika’ya, Basra Körfezine yönelik büyük göç dalgalarının sonucu olarak oluşmaktadır (Sheffer, 1986, s. 1-15). Sheffer'ın kronolojik yaklaşımı, diaspora kavramının güncel yorumu açısından son derece değerlidir; tarihsel diaspora ve modern diaspora ayrımı, kavramsal ve kuramsal çerçeveyi belirlemeyi kolaylaştırmaktadır.

Robin Cohen, diasporaları 5 başlık altında sınıflandırmaktadır:

a. Mazlum diasporalar (Victim diasporas): Yahudiler, Filistinliler, İrlandalılar, Afrikalılar ve Ermeniler.

b. Emek diasporaları (Labour diasporas): Hintliler, İtalyanlar, Türkler.

c. Emperyal Diasporalar (Imperial diasporas): İspanyollar, Portekizler, Hollandalılar, Almanlar, Fransızlar, İngilizler.

d. Ticaret diasporaları (Trade diasporas): Çinliler, Lübnanlılar.

e. Kültürel diasporalar (Cultural diasporas): Karayipliler.

Cohen (1997, s. 179), bu yaklaşımın keskin çizgiler içeremeyeceğini açıklayarak, ilgili diaspora gruplarının zaman içerisinde değişebileceğini ve bu başlıklardan birkaçıyla örtüşebileceğini belirtmektedir. Yahudilerin hem mazlum diaspora hem işçi diasporası, hem ticaret diasporası hem de kültürel diaspora olarak değerlendirilebilecek olması da bu duruma bir örnektir. Cohen’in bu yaklaşımının, kavramın güncel yorumuna sınırlı bir katkısı olabilecektir. Tematik yaklaşım, bir diaspora grubunun (Yahudi diasporası) dört tematik gruba 


\section{Firat Yaldız}

da dâhil ederek, sınıflandırma çabalarının ortaya çıkış noktasını anlamsızlaştırmaktadır. Bu yaklaşım, hem tarihsel ve güncel gelişmelerin diaspora olgusuna etkisini önemsizleştirmekte hem de tematik sınıflandırmanın işe yararlığını zedelemektedir.

Sheffer (2003, s. 23), diasporaların ilişkide oldukları anavatanın siyasi durumu bağlamında, devleti olan (statelinked) diaspora ve devletsiz (stateless) diaspora ayrımı yapmakta ve devletsiz diasporayı, diasporanın kökeni olan anavatanın bilinmediği veya başka bir ulus tarafından yönetildiği durumlar için kullanmaktadır. $\mathrm{Bu}$ sınıflandırma, -diaspora olgusunun genel çerçevesini çizmek için yetersiz olsa da- akraba devlet - diaspora ilişkileri açısından önemlidir.

Diaspora kavramının içeriğinin, dönemsel gelişmeler bağlamında zenginleştiğini belirten Michele Reis, “Theorizing Diaspora: Perspectives on 'Classical' and 'Contemporary' Diaspora” başlıklı makalesinde (2004, s. 41-56), diasporaları 3 ayrı dönemde incelemektedir: (i) Klasik Dönem (tarihsel diasporalar: Yunan diasporası, Yahudi diasporası), (ii) Modern Dönem (1500-1945) (iii) Çağdaş (veya Geç-Modern) dönem (1945 sonras1).

Reis, Klasik Dönem'de temel olarak Antik Çağ ve sonrasını kastetmekte, Yahudi Diasporasına ve bu dönemde oluşmaya başlayan Ermeni Diasporasına atıf yapmaktadır.

Modern Dönemi ise, (i) Avrupa Pazarının genişlediği 1500-1814 arası dönem, (ii) 1815-1914 arası Sanayi Devrimi Dönemi, (iii) İki Dünya Savaşı arası dönem (1914-1945) olarak üç alt döneme ayırmaktadır. Bu dönemde meydana gelen siyasi gelişmeler nedeniyle değişen coğrafi ve politik sınırlar, özellikle kölelik ve kolonizasyon süreçleri, diaspora olgusunu Klasik Dönemden daha farklı boyutlarda etkilemiştir. Ancak Reis (2004, s. 42), Klasik Dönem ve Çağdaş Dönemi karşılaştırmalı olarak incelemeye odaklandığı için, Modern Dönemi incelemediğini belirtmektedir.

Reis, çalışmasında, 2. Dünya Savaşı'nın hemen sonrasında başlayıp günümüze kadar devam eden Çağdaş Dönem'in diaspora olgusuna etkisini, ABD'deki hispanicler üzerinden incelemektedir. Reis'in bu yaklaşımı, kavramın içeriğini ve diaspora toplumlarının niteliğini, tarihsel süreç ve küresel/politik gelişmelerle birlikte yorumlaması nedeniyle daha açıklayıcı görünmektedir. Diaspora kavramının, yukarıdaki üç tarihsel dönem bağlamında değiştiği, dünya genelinde meydana gelen sanayi devrimi, küreselleşme, dünya savaşları gibi gelişmelerden etkilendiği düşüncesi, günümüz diaspora toplumlarını yorumlamaya daha uygun bir altyapı hazırlamaktadır.

Ancak yukarıda bahsedilen bu sınıflandırmalar, Batı siyasi tarihine ilişkin (Avrupa pazarının genişlemesi, Sanayi

Devrimi, I. ve II. Dünya Savaşları gibi) dinamikler göz önüne alınarak yapıldığı için, genel olarak Türkiye dışındaki Türkleri kapsayabilmekten uzaktır. Oniki Ada Türk Toplumu özelinde ise, modern dönemde kökleri 
atılan çağdaş döneme ilişkin ve diaspora olma potansiyeli taşıyan bir toplumdan söz etmek mümkündür. Bu bağlamda, mevcut çalışmaların bu bakış açısıyla genişlemesi ve zenginleşmesi gereklidir.

Dolayısıyla, diasporaların özelliklerine ilişkin kuramsal çerçevenin, diasporaların sınıflandırılması bağlamında da On İki Ada Türk toplumunu tam olarak kapsamadığı değerlendirilmektedir. Yahudiler ve Ermeniler gibi verili toplumsal örneklerden yola çıkarak yürütülen diaspora çalışmalarının, bu anlamda önemli bir eksikliği ortaya çıkmaktadır. Buna rağmen, On İki Ada Türk Toplumunun kökü modern döneme uzanan Çağdaş diaspora olma potansiyeli taşıdığını söylemek mümkündür.

\section{On İki Ada Türk Toplumu ve Diaspora İlişskisi Açısından Bireysel Haklar}

Yukarıda açıklandığı üzere, diaspora çalışmalarına ilişkin tartışmalar ve tanımlamalar açısından On İki Ada Türk toplumunu, diaspora olarak tanımlamak mümkün gözükmemektedir. Ancak On İki Ada Türk toplumunu, mevcut 


\section{Firat Yaldız}

durumu itibariyle, önemli ölçüde diaspora olma potansiyeli taşımaktadır. Bu bağlamda, dil, din, kimlik üzerinden devam etmekte olan toplumsal bilinç, güncel gelişmeler ışığında yorumlanmalıdır.

“On İki Ada Türk Toplumu diaspora olarak tanımlanmalı mıdır?” sorusu, bu noktada önemli bir konu olarak karşımıza çıkmaktadır. Bu çalışmada bu soruya verilen cevap açık bir şekilde "Evet”tir. Çünkü, ilk olarak, "[D]iaspora toplumlarının, küresel sistemde artan etkisiyle doğru orantılı olarak, diaspora kavramının da -azınlık kavramında olduğu gibi- hukuki tartışmaların, sosyal - siyasal düzenlemelerin ve akademik araştırmaların (daha) güçlü bir öznesi olacağı öngörülmektedir.” (Yaldız, 2013, s. 312)

İkinci olarak diaspora olmak, dil, din, kültür gibi kimliğe ilişsin değerlerin korunmasına yardımcı olmaktadır. Bu bağlamda, kültürel zenginliklerin evrensel değerler olarak görüldüğü günümüz dünyasında, asimilasyon yerine uyumu ön plana çıkaran söylemlerin önemini vurgulamak gerekir. Nitekim bireysel haklar konusu da bu süreçle eşzamanlı olarak yasal ve sosyal anlamda genişlemektedir. "[U]luslararası hukuka uygun anlaşmalarla azınlık statüsü elde etmiş gruplar, bazen grup hakkı boyutuna da varan azınlık haklarını kullanmaya ve korumaya devam etme[s]i, ancak hukuki statüye sahip yeni azınlık gruplarının oluşmaması için, bireysel haklar[ın] genişletilme[si]" (Yaldız, 2012, s. 142) şeklinde özetlenebilecek insan hakları bağlamındaki uluslararası tartışmalar ve hukuki düzenlemeler, On İki Ada Türk toplumu açısından da önemli firsatlar sunmaktadır. ${ }^{7}$

Yunanistan vatandaşı olan On İki Ada Türkleri için ulusal (Yunanistan) uygulamalar ve Avrupa Birliği (AB) uygulamalarında meydana gelen gelişmeler önem taşımaktadır. Heraclides (Heraclides, 2003, s. 297) Yunanistan'ın resmi tutumunun, dar bir hukuki yoruma dayandığını belirterek, bu yorumu "[b]ir azınlığın varlığı hukuksal bir konu olup, ülken kendi yasalarında ya da uluslararası bir antlaşmadan (örneğin Lozan Antlaşması gibi) saptanır. Azınlık hakları ve bu konuda devletin yükümlülükleri yalnız bu yoldan oluşur.” şeklinde özetlemekte ve "bu düşünce biçimi[ni] yasal açı çerçevesinde bile çok sınırlı olup çağımızın anlayışı ve istekleriyle uyum içinde değildir" diyerek eleştirmektedir. Dolayısıyla "Batı Trakya'daki Türk azınlık, Yunanistan'ın varlığını resmen tanıdığı tek azınlık” olduğu için, (Öksüz, 2006, s. 7) On İki Ada Türk toplumunun -diaspora bilinci açısından da büyük önem taşıyan- dil, din, kimlik gibi değerlerinin korunması ve geliştirilmesi için azınlık hakkı talep etmelerinin, yasal düzenlemeler/yorumlar ve pratik uygulamalar açısından

\footnotetext{
${ }^{7}$ İnsan haklarına iliş̧kin en önemli başlıca belgeler olduğu değerlendirilen, BM İnsan Hakları Sözleşmesi, AK Avrupa İnsan Hakları Sözleşmesi ve AB Temel Haklar Şartında da, azınlık haklarının bireysel hak boyutundaki (kanun önünde eşitlik, ayrımcılık yasağı gibi) maddelere rağmen, grup hakkı boyutunda hiçbir düzenlemeye yer verilmediği görülmektedir. Başka bir anlatımla, insan haklarına ilişkin uluslararası algının ve uluslararası belgelerin, grup haklarını insan haklarının parçası olarak görmediği değerlendirilmektedir. Bu çalışmada da, grup haklarının grup üyeliğinin hakka erişim için zorunluluk olması nedeniyle, bütün insanların doğuştan sahip olduğu haklar olduğu kabul edilen evrensel insan hakları yaklaşımıyla uyum göstermediği ve dolayısıyla grup haklarının insan haklarının parçası olamayacağı kabul edilmektedir
} 
sonuca varmayacağı açıktır. Bu noktada vurgulanması gerekir ki On İki Ada Türk toplumunun, diaspora bilincini de olumlu yönden etkileyecek hak taleplerini, bireysel hakların geliştirilmesi bağlamında gündeme getirmesi, politik açıdan daha doğru olacaktır. Nitekim AB'nin grup haklarından bireysel hakların gelişimine ilişsin yaklaşımını zaman içerisinde netleştirdiği, AB raporlarında kullanılan kavramlarda dahi görülmektedir. 1999 yılından beri yıllık olarak yayınlanan (toplam 13) “AB İnsan Hakları Raporları”nda sırasıyla "azınlıklar” [ (European Union, 1999), ve (European Union , 2000) raporları], “azınlıklara mensup bireyler” [ (European Union, 2001), (European Union, 2002), (European Union, 2003), (European Union , 2004), (European Union , 2005) ve (European Union, 2006) raporları] ve "azınlıklara mensup birey hakları" [ (European Union , 2007), (European Union , 2008), (European Union , 2009), (European Union , 2010), (European Union , 2011) ve (European Union, 2012) raporları)] şeklinde bir kavramsallaştırmaya gidilmiş olması da bu değişimi yansıtan önemli bir ayrıntıdır. AB'nin retorik olarak da grup’u değil birey’i özne olarak görmeye başlaması “azınlıklar azınlıklara mensup bireyler - azınlıklara mensup birey hakları” kavramlarındaki değişim ve dönüşümde ifade bulmaktadır. Üstelik bu kavramsal gelişimin, "insan hakları" ile ilgili bir raporda yaşanması da önemli ve değerli bir ayrıntıdır.

\section{Sonuç}

Günümüzde çok daha sık ve kolay kullanılmaya başlanan bir kavram olan diasporanın, ifade etmesi gereken kavramsal çerçevesi genişlemiş ve belirsizleşmiştir. Bu durumun da etkisiyle, kavramın anlamını belirleme ihtiyacı ortaya çıkmış ve literatürde diasporaya ilişkin (diasporaların özellikleri ve sınıflandırılması gibi çeşitli başlıklarda) tartışmalar yoğunlaşmış ve uluslararası ilişkiler araştırmalarını da zenginleştiren çok değerli eserler üretilmiştir. Bu gelişmelere rağmen, diaspora kavramına ilişkin genel kabul görmüş bir tanımdan bahsetmek mümkün değildir. Türkiye'de, yurtdışındaki Türk varlığına yönelik kurumsal ilgi artmış olmakla birlikte, diaspora kavramı ile ilgili akademik araştırmaların son derece yetersiz olduğu görülmektedir.

Bu çalışmanın merkezinde yer alan On İki Ada Türk Toplumunun, tarihsel kökenleri ve toplumsal dinamikleri açısından özel bir duruma sahip olduğu görülmektedir. Türkiye ile ilişkileri kesintisiz bir şekilde devam etmekle birlikte, hukuken Yunanistan vatandaşı olan On İki Ada Türk Toplumu üyeleri, uluslararası hukuk açısından Yunanistan - Batı Trakya'daki azınlık statüsüne sahip Türk toplumundan da ayrışmaktadır. Bu çalışmada, yukarıda açıklanan konuların On İki Ada Türk Toplumu açısından ortaya çıkardığı özel durum, diaspora tartı̧maları bağlamında incelenmiş ve diaspora bilincinin, asimilasyonu engelleyen ve entegrasyonu güçlendiren bir boyuta ulaşabileceği belirtilmiştir. 
60 Firat Yaldız

On İki Ada Türk Toplumunun diaspora kimliğinin güçlenmesi, kimlik, dil, eğitim, tarihi miras gibi sorunlarla yakından ilişkilidir. Ayrıca, diaspora toplumlarının küresel sistemde, özellikle ekonomik ve politik açıdan önemli bir yere erişmesinin etkisiyle, On İki Ada Türk Toplumunun, Türkiye, Yunanistan ve Avrupa Birliği ilişkilerinde köprü rolü üstlenebileceği değerlendirilmektedir.

Son olarak, grup hakkı yaklaşımı yerine bireysel hakların geliştirilmesi yönündeki uluslararası eğilimin, Avrupa Birliği tarafından da destekleniyor olmasının etkisiyle, On İki Ada Türk toplumunun, bireysel hak talepleri üzerinden sürdürebilecekleri politik girişimler, toplumsal yapının güçlenmesine katkı sağlayabilecektir. 


\section{KAYNAKÇA}

Armstrong, J. A. (1976, June). Mobilized and Proletarian Diasporas. American Political Science Review(70 (2)), s. 393-408.

Balducci, H. (1987). Rodos'ta Türk Mimarisi. Ankara: Türk Tarih Kurumu.

Bastıyalı, M. (1999). Rodos ve Onikiadalar Tarihi. İzmir: Yayınevi Belirtilmemiştir.

Belge, M. (2011). Sunuş. S. Dufoix içinde, Diasporalar. İstanbul: Hrant Dink Vakfı Yay.

Boyarin, D., \& Boyarin, J. (2007). Diaspora: Generation and the Ground of Jewish Identity. A. Mannur, \& J. E. Braziel içinde, Theorizing Diaspora: A Reader. Oxford: Blackwell Pub.

Brackman, H. (2010). Jews, African Americans and Israel: The Ties That Bind. Simon Wiesenthal Center/Museum of Tolerance, 2.

Braziel, J. E., \& Mannur, A. (2007). Nation, Migration, Globalization: Points of Contention in Diaspora Studies. J. E. Braziel, \& A. Mannur içinde, Theorizing Diaspora: A Reader. Oxford: Blackwell Pub.

Brubaker, R. (2005, January). The 'diaspora' Diaspora. Ethnic and Racial Studies(28), s. 1-19.

Clifford, J. (1994). Diasporas. Cultural Anthropology(9(3)), s. 302-338.

Cohen, R. (1997). Global Diasporas: An Introduction. Londra: UCL Press.

Cohen, R. (1999). Diaspora and the nation-state: from victims to challengers. S. Vertovec, \& R. Cohen içinde, Migration, Diasporas and Transnationalism (s. 266). Massachusetts: Edward Elgar Pub.

Cohen, R. (2001). Diaspora. International Encyclopedia of the Social and Behavioral Sciences (s. 3642-3645). içinde Amsterdam: Elsevier. 
Çelikkol, Z. (1992). Rodos'taki Türk Eserleri ve Tarihçe. Ankara: Türk Tarih Kurumu Basımevi.

Dufoix, S. (2011). Diasporalar. İstanbul: Hrant Dink Vakfı Yay.

European Union . (2000). European Union Annual Report on Human Rights 2000. European Union.

European Union . (2002). European Union Annual Report on Human Rights.

European Union . (2004). European Union Annual Report on Human Rights.

European Union . (2005). European Union Annual Report on Human Rights.

European Union . (2007). European Union Annual Report on Human Rights.

European Union . (2008). European Union Annual Report on Human Rights.

European Union . (2009). European Union Annual Report on Human Rights.

European Union . (2010). European Union Annual Report on Human Rights.

European Union . (2011). European Union Annual Report on Human Rights.

European Union. (1999). European Union Annual Report on Human Rights 1998/99. European Union.

European Union. (2001). European Union Annual Report on Human Rights.

European Union. (2003). European Union Annual Report on Human Rights.

European Union. (2006). European Union Annual Report on Human Rights.

European Union. (2012). European Union Annual Report on Human Rights.

Gilroy, P. (1993). The Black Atlantic: Modernity and Double Consciousness. New York: Verso Pub.

Heraclides, A. (2003). Yunanistan ve Doğudan Gelen Tehlike Türkiye. İletişim Yayınları.

Irele, A. (1965, October). Negritude or Black Cultural Nationalism. The Journal of Modern African Studies, 3(3), s. 321-348. 
Lowe, L. (2007). "Heterogeneity, Hybridity, Multiplicity: Marking Asian-American Differences”,. E. Braziel, \& A. Manur içinde, Theorizing Diaspora: A Reader (s. 132155). Oxford: Blackwell Pub.

Marienstras, R. (1999). On the Notion of Diaspora. S. Vertovec, \& R. Cohen içinde, Migration, Diaspora and Transnationalism. Massachusetts: Edward Elgar Pub.

Meinardus, R. (2002). Muslims: Turks, Pomaks and Gypsies. R. Clogg içinde, Minorities in Greece: Aspects of Plural Society (s. 81-93). London: C. Hurst \& Co. (Publishers Ltd.).

Öksüz, H. (2006). Batı Trakya Türkleri. Çorum: Karam Yayınları.

Pergola, S. D. (2010). World Jewish Population 2010. 8 28, 2012 tarihinde http://www.jewishdatabank.org/Reports/World_Jewish_Population_2010.pdf adresinden alınd 1

Radhakrishnan, R. (2007). Ethnicity in an age of Diaspora. E. Braziel, \& A. Manur içinde, Theorizing Diaspora: A Reader (s. 119-131). Oxford: Blackwell Pub.

Reis, M. (2004, June). Theorizing Diaspora: Perspectives on 'Classical' and 'Contemporary' Diaspora. International Migration, 42(2), 41-56.

Safran, W. (1999). Diasporas in Modern Societies: Myths of Homeland and Return. S. Vertovec, \& R. Cohen içinde, Migration, Diasporas and Transnationalism. Massachusetts: Edward Elgar Pub.

Sheffer, G. (1986). A New Field of Study: Modern Diasporas in International Politics. G. Sheffer içinde, Modern Diasporas in International Politics (s. 1-15). London: Croom Helm.

Sheffer, G. (2003). Diaspora Politics, At Home Abroad. Cambridge: Cambridge University Press. 
Shepperson, G. (1966). The African Abroad or the African Siaspora. African Forum 2, (s. 76) .

Sideri, E. (2008). The Diaspora of the Term Diaspora: A Working-Paper of a Definition. Cultures in Transit(4), 32-47.

Tölölyan, K. (1991). The Nation-State and Its Others: In Lieu of a Preface. Diaspora: A Journal of Transnational Studies, 1(1), 4.

Yaldı, F. (2012, Güz). AB'de Bireysel Haklar ve Lizbon Antlaşması. Bilge Strateji, 4(7), 122-146.

Yaldız, F. (2012). AB'de Bireysel Haklar ve Lizbon Antlaşması. Bilge Strateji, 122-146.

Yaldız, F. (2013). Diaspora Kavramı: Tarihçe, Gelişme ve Tartışmalar. Hacettepe Üniversitesi Türkiyat Araştırmaları Dergisi, 289-318.

Yaldız, F. (2014). Uluslararası Göç ve Diaspora ile İlişkili Kavramlar. İnsan ve Toplum Bilimleri Araştırmaları Dergisi, 3(2), 382-403. 